\title{
KONSEP PEMBELAJARAN DARING DI ERA PANDEMI COVID-19
}

Devi Fitriya $^{1}$, Ina Magdalena ${ }^{2}$ dan Nur Fauziah Fadhillahwati ${ }^{3}$

Universitas Muhammadiyah Tangerang, Indonesia

devifitriya16@gmail.com, inapgsd@gmail.com,dhiweh.id25@gmail.com

Received: 06-03-2021

Revised: $\quad 10-03-2021$

Accepted: $20-03-2021$

\begin{abstract}
This study aims to analyze the learning process online, how is the level of readiness of teachers in organizing online learning, how is the level of readiness of students in receiving online learning. The supporting factors and inhibiting in implementing the courage system learning during the COVID-19 pandemic.This study was conducted at SDN Cengkareng Barat 16 Pagi. This research is qualitative. The data subject in the study were elementary school teacher at SDN Cengkareng Barat 16 Pagi. The data collection techniques in this study were in the form of semi-structured interviews, documentation, and open questionnaires. The result of this study are the impact of COVID-19 pandemic is huge on the learning process, usually learning is carried out directly, but know it is converted into online learning. Students feel so bored while carrying out learning. For elementary school aged children it is deemed ineffective in learning online.
\end{abstract}

Keywords: COVID-19; supporting

factors, inhibiting factors; online learning.

\begin{abstract}
Abstrak
Penelitian ini bertujuan untuk menganalisis proses pembelajaran melalui daring, bagaimana tingkat kesiapan guru dalam menyelenggarakan pembelajaran daring, bagaimana tingkat kesiapan siswa dalam menerima pembelajaran sistem daring. Faktor-faktor pendukung serta faktor-faktor penghambat dalam melaksanakan pembelajaran sistem daring di masa pandemi COVID-19. Penelitian ini dilaksanakan di SDN 16 Pagi Cengkareng Barat. Penelitian ini bersifat kualitatif. Subjek data dalam penelitian adalah guru sekolah dasar di SDN Cengkareng Barat 16 Pagi. Teknik pengumpulan data dalam penelitian ini berupa, wawancara semi terstruktur, dokumentasi, angket terbuka dan hasil catatan lapangan. Hasil penelitian ini adalah dampak dari pandemi COVID-19 sangat besar terhadap proses pembelajaran, biasanya pembelajaran dilaksanakan secara langsung, namun kini dialihkan menjadi pembelajaran daring. Peserta didik merasa bosan dan jenuh selama melaksanakan pembelajaran. Untuk anak usia sekolah dasar dirasa kurang efektif melakukan pembelajaran melalui daring.
\end{abstract}

Kata kunci: COVID-19; faktor pendukung; faktor penghambat; pembelajaran daring 


\section{PENDAHULUAN}

COVID-19 atau Corona Virus ditemukan di Tiongkok pada Desember 2019. Virus Corona menyebabkan penderitanya mengalami gejala ringan seperti mual, demam, dan batuk kering, sedangkan untuk gejala beratnya penderita bisa mengalami Middle East Respiratory Syndrome (MERS) dan Severe Acute Respiratory Syndrome (SARS) (Kementerian Kesehatan, 2020). Untuk mengurangi resiko penyebaran COVID, pemerintah menerapkan peraturan work from home (WFH) atau bekerja dari rumah dan diberlakukan juga sistem pembelajaran jarak jauh untuk para peserta didik maupun mahasiswa. Sehingga proses pembelajaran harus menyesuaikan dengan keadaan. Proses pembelajaran adalah interaksi antara guru, peserta didik dengan lingkungannya sehingga perubahan perilaku terjadi ke arah yang lebih baik. Dalam interaksi tersebut pengaruhnya sangat banyak, baik faktor internal dari dalam individu, maupun faktor eksternal yang datang dari lingkungan Marquis \& Hilgard (Suyono \& Hariyanto, 2016: 12) menyatakan "belajar adalah proses mencari ilmu dalam diri seseorang yang terjadi melalui, pembelajaran, pelatihan dan lain-lain sehingga terjadi perubahan dalam diri seseorang". Menurut undang-undang nomor 20 tahun 2003 pembelajaran adalah proses interaksi peserta didik dengan pendidik dan sumber belajar pada lingkungan belajar. Pendidik harus memenuhi kualifikasi sesuai dengan tingkatan peserta didik yang diajari, pelajaran yang diampu, dan ketentuan yang intruksional lainnya. Disamping itu, pendidik harus menguasai sumber belajar dan media pembelajaran agar tercapai tujuan pembelajaran (Pohan, Albert, 2020).

(Susanti, 2020) Eggen \& Kauchak (2012) menyatakan bahwa guru. pengajaran yang baik merupakan faktor terpenting dalam proses pembelajaran bahkan lebih penting daripada kurikulum yang digunakan, pengaturan ruang kelas, ukuran ruang kelas, sarana dan prasarana sekolah. Pengajaran yang baik meliputi penguasaan guru terhadap materi yang akan disampaikan memahami karakteristik peserta didik mampu merancang pembelajaran dan menyajikan ulang materi selanjutnya. Untuk itu, maka guru harus memiliki keterampilan dalam mendesain pembelajaran yang dan efisien. Berkaitan dengan interaksi dalam pembelajaran menulis sebagai suatu proses, mengisyaratkan kepada guru untuk memberikan bimbingan nyata dan terarah yang dapat meningkatkan kemampuan menulis siswa. Pembelajaran merupakan inti dari proses pendidikan. Kualitas pendidikan menggambarkan kualitas pembelajaran. Pembelajaran secara daring dan bekerja dari rumah bagi para pendidik merupakan perubahan yang harus dilakukan oleh guru dan dosen untuk tetap mengajar siswa dan mahasiswa. Dengan kata lain, pembelajaran adalah proses untuk membantu peserta didik agar dapat belajar dengan baik. Proses pembelajaran dialami sepanjang hayat seorang manusia serta dapat berlaku di manapun dan kapanpun (Suardi, 2018). Tujuan dari pembelajaran jarak jauh (PJJ) agar mutu, relevansi, pemerataan akses dan perluasan pendidikan meningkat. Pendidikan jarak jauh yang diselenggarakan dengan jaminan kualitas yang baik dan serta sesuai dengan kebutuhan para pendidik, peserta didik maupun mahasiswa merupakan salah satu mekanisme perluasan akses pendidikan tinggi.

Program Belajar Jarak Jauh (PBJJ) merupakan konsep yang digunakan saat ini oleh setiap sekolah dan universitas untuk melaksanakan proses belajar mengajar dengan tidak tatap muka secara langsung. Proses belajar mengajar dari tatap muka berubah 
menjadi PBJJ yang harus dilakukan oleh sekolah agar tujuan pendidikan dapat dilaksanakan secara efektif dan efisien. Sekolah di tengah pandemi COVID-19 harus tetap menjalankan proses belajar mengajar. Dengan mengubahnya menjadi PBJJ, PBJJ ini menjadi tantangan bagi setiap universitas untuk tetap menjalankan tujuan pendidikan. Pandemi COVID-19 telah membukakan cara pandang dan kebiasaan baru mengenai proses pembelajaran yang idealnya melibatkan guru, siswa dan orangtua. Perubahan situasi dari pembelajaran yang selama ini lebih berfokus pada peran guru, sekarang mulai beralih pada situasi dimana orang tua dan guru saling berbagi peran dalam memfasilitasi pembelajaran siswa (Sarwa, 2021).

Pada saat sekarang ini fungsi tenaga pengajar seperti Guru sangat diperlukan kenapa?, karena walaupun peserta didik dirumahkan guru harus tetap mengajar juga, karena guru mempunyai peranan yang sangat strategis dan penting dalam keseluruhan upaya pendidikan. Hampir semua usaha pembaharuan di bidang kurikulum dan penerapan metode mengajar guru, pada akhirnya tergantung pada guru itu sendiri. Guru adalah orang yang membuat, dan melaksanakan proses dalam pembelajaran tersebut, guru juga menilai setiap peserta didik serta membimbing peserta didik untuk meraih cita-cita dan memiliki akhlak yang baik (Nur, A. M. 2011). Pada sisi ini guru sangat berperan penting untuk menjalankan kurikulum, apa itu pengertian kurikulum. Kurikulum dipahami sebagai susunan mata pelajaran yang diajarkan pada jenjang pendidikan. Secara sederhana pernyataan tersebut tidak sepenuhnya keliru. Namun pemahaman ini harus diperdalam karena kurikulum tidak hanya berkenaan dengan mata pelajaran. Menurut Undang-undang Nomor 20 Tahun 2003 Pasal 1 Ayat (19) Kurikulum adalah seperangkat rencana dan pengaturan mengenai tujuan, isi, dan bahan pelajaran serta cara yang digunakan sebagai pedoman penyelenggaraan kegiatan pembelajaran untuk mencapai tujuan pendidikan tertentu (Syaharuddin, S., \& Mutiani, M. 2020) kita dirumahkan sebagai langkah untuk bertujuan mendukung kebijakan pemerintah agar selanjutnya yakni menghambat atau memutuskan rantai COVID-19 tersebut dengan dirumah saja.

Pendidik merasa terkejut karena harus mengubah kurikulum, silabus, rencana pelaksanaan kegiatan serta materi pembelajaran secara cepat. Siswa merasa gagap karena mendapat tumpukan tugas selama belajar dari rumah. Selain itu, orang tua murid juga merasa stress ketika mendampingi kegiatan belajar mengajar anaknya di rumah dengan tugas-tugas, di samping harus memikirkan aktivitas sehari-hari demi keberlangsungan hidup dan pekerjaan masing-masing di tengah pandemi ini.

Dari beberapa masalah tersebut yang pada akhirnya menjadi catatan penting dari dunia pendidikan yang harus segera ditentukan langkah untuk mengejar pembelajaran daring secara cepat. Padahal, secara teknis dan sistem belum semuanya siap. Padahal, pembelajaran online bukan metode untuk mengubah belajar tatap muka dengan aplikasi daring, bukan juga membebani siswa dengan memberikan banyak tugas setiap hari. Pembelajaran secara daring harusnya mendorong siswa menjadi kreatif mengakses sebanyak mungkin sumber pengetahuan, menghasilkan karya, mengasah wawasan dan pada akhirnya menjadikan siswa sebagai insan kamil, memiliki kecakapan pola berfikir serta kecakapan hidup.

Tujuan ditulisnya artikel ini sebagai informasi atau pengetahuan tentang konsep bagaimana pembelajaran daring yang sudah terjadi satu tahun di Indonesia yang membuat lemah segala sektor, termasuk sektor pendidikan, di mana pihak yang diajak wawancara diminta pendapat, dan ide-idenya. Wawancara dilaksanakan bersama guru kelas I SDN Cengkareng Barat 16 Pagi. 


\section{METODE PENELITIAN}

Penelitian ini dilakukan di SDN Cengkareng Barat 16 Pagi, Jakarta. Metode dalam penelitian ini adalah metode deskriptif kualitatif. Kehadiran peneliti di SDN 16 Cengkareng Barat adalah sebagai Subyek Penelitian, sedangkan prosedur pengumpulan data yang dilakukan peneliti menggunakan metode wawancara, yaitu metode pengumpulan data dengan menggunakan langkah tanya jawab secara lisan dengan sumber penelitian, dan metode dokumentasi yaitu mencari data dengan mencatat atau mengutip dari dokumen atau prinsip-prinsip yang diperlukan untuk melengkapi data yang diperoleh langsung dari responden.

Teknik pengumpulan data dilakukan dengan cara observasi, angket, wawancara, dan dokumentasi untuk mendapatkan hasil tentang analisis konsep pembelajaran daring di masa pandemi COVID-19. Pada penelitian ini yang digunakan adalah wawancara semi struktural (semi structured interview). Menurut Sugiyono (2015: 320) jenis wawancara ini termasuk dalam kategori in-depth interview, dimana pelaksanaannya lebih bebas dan terbuka dibanding dengan wawancara terstruktur.

\section{Angket}

Angket adalah set pertanyaan secara logis berhubungan dengan masalah penelitian (Minto, 2009). Angket diberikan kepada guru Kelas 1 di SDN 16 Pagi Cengkareng Barat. Angket dalam penelitian ini merupakan angket terbuka, dimana merupakan angket tertulis yang pertanyaannya dijawab oleh responden. Tujuan penggunaan angket ini untuk mendapatkan informasi pelaksanaan proses pembelajaran secara daring di era pandemi COVID-19 serta faktor-faktor pendukung dan juga penghambat guru dalam melaksanakan proses pembelajaran di SDN Cengkareng Barat 16 Pagi.

\section{Wawancara}

Wawancara dalam penelitian ini menggunakan jenis wawancara semi terstruktur terhadap seorang guru kelas I di SDN Cengkareng Barat 16 Pagi yaitu sebagai responden. Tujuan wawancara ini dilakukan untuk memperdalam data yang diperoleh dari angket.

\section{HASIL DAN PEMBAHASAN}

\section{Hasil}

Berdasarkan hasil penelitian secara langsung yang didapat dari angket terbuka dan wawancara semi struktur. Hasil penelitian ini diperoleh dalam penelitian COVID-19 yang terjadi di Indonesia sudah merugikan banyak sektor, seperti sektor ekonomi, sektor pariwisata, sektor transportasi dan sektor Pendidikan. Pada saat pandemic COVID-19 semua dilakukan dirumah termasuk sektor Pendidikan yang menerapkan konsep Pembelajaran Jarak jauh (PJJ).

Dari segi fasilitas pendukung untuk pembelajaran daring bagi siswa ada beberapa kendala, seperti hanya beberapa siswa yang memiliki handphone/laptop, pemahaman siswa tentang teknologi yang kurang, handphone siswa tidak bisa mensupport aplikasi belajar daring seperti zoom meeting atau yang lainnya. Media yang digunakan guru saat belajar daring untuk siswa kelas 1 menggunakan laptop atau google meet 2 kali dalam seminggu, serta alat penunjang seperti handphone hanya digunakan untuk pemberian informasi. Dan untuk guru pengajar menggunakan media google classroom atau aplikasi yang sudah disediakan dari pihak sekolah. 
Kemudian hal lain yang dilakukan oleh guru untuk menciptakan suasana belajar yang kondusif dengan cara menciptakan permainan untuk para siswa yang berhubungan dengan pelajaran. Suasana belajar itu diciptakan agar para siswa bersemangat dan tidak cepat bosan. Dalam keadaan pandemic COVID 19 ini, pembelajaran tidak bisa seefektif sebelumnya, karena guru tidak bisa menyaksikan secara langsung keterampilan siswa dalam menjawab atau memahami materi dan soal, siswa pun tidak bisa memahami penjelasan guru secara langsung. Guru tidak mengetahui secara pasti apakah hasil tersebut real dari siswa atau ada campur tangan orang tuanya. Sedangkan belajar offline lebih objektif karena guru melihat dari keterampilan dan kebiasaan para siswa yang dilakukan di sekolah. Harapan para guru untuk belajar daring semoga segera berakhir karena sangat berbeda keefektifan antara pembelajaran online dan offline. Nilai positif dari pembelajaran daring siswa lebih paham tentang teknologi, namun disisi lain nilai negatifnya guru tidak mengetahui sifat anak secara langsung dengan jelas dan terbukti guru tidak bisa digantikan oleh teknologi.

\section{Pembahasan}

Dari hasil penelitian menggunakan metode kualitatif deskriptif melalui teknik pengumpulan data berupa angket dan wawancara yang telah dilakukan pada guru di SDN Cengkareng Barat 16 Pagi, dalam proses pembelajaran daring serta faktor-faktor pendukung dan faktor-faktor penghambat guru dalam melaksanakan pembelajaran daring di masa pandemi COVID-19 dapat disimpulkan, dampak pandemi COVID-19 pada dunia pendidikan. Terjadinya pandemi ini membuat proses belajar mengajar sangat terganggu, biasanya proses pembelajaran yang dilaksanakan dengan tatap muka langsung antara peserta didik dan guru di kelas, selama pandemi berubah menjadi pembelajaran daring. Menurut (Sari 2015) pembelajaran daring memiliki kelebihan dapat membangun suasana belajar baru, suasana yang baru bagi peserta didik dalam melaksanakan pembelajaran, biasanya dilakukan di kelas, suasana baru membuat peserta didik menumbuhkan antusias dalam belajar. Sedangkan Menurut Purwanto (2020: 6) dampak lain dari pandemi COVID-19 terhadap peserta didik yaitu membuat peserta didik bosan dan jenuh dan ingin segera berinteraksi langsung dengan teman-temannya, bermain dan bercanda dengan teman-temannya. Selain itu guru mengungkapkan bahwa pembelajaran daring untuk anak sekolah dasar masih banyak kendalanya. Keikutsertaan peserta didik dalam pembelajaran daring juga tidak mencapai $100 \%$. Pembelajaran daring menggunakan whatsapp sebagai media guru menyampaikan materi dan mengirim tugas terhadap peserta didik. (Dewi 2020) belajar daring dapat menggunakan teknologi digital, namun yang pasti dalam pemberian tugas harus melalui pemantauan pendampingan oleh guru melalui whatsapp grup sehingga anak benar-benar belajar. Guru melakukan proses sistem penilaian yang sama dengan sistem penilaian pembelajaran biasanya. Peran orang tua dalam pembelajaran daring juga tidak lepas, mengingat usia anak sekolah dasar yang masih perlu dibimbing juga pengawasan dalam pembelajaran. Dalam pembelajaran daring motivasi dari guru sangat diperlukan oleh peserta didik agar tetap semangat dan tidak mudah jenuh mengikuti pembelajaran. Dengan cara memberikan tugas yang menarik dan menyenangkan serta seluruh guru bisa dengan membuat sebuah video berisi memberikan semangat kepada peserta didik meskipun harus melaksanakan pembelajaran daring.

\section{KESIMPULAN}

Kegiatan belajar mengajar diliburkan sementara, pembelajaran tatap muka di gantikan dengan kegiatan pembelajaran secara daring. Pembelajaran daring yang 
dilaksanakan dengan menggunakan koneksi internet atau data seluler, dan menggunakan aplikasi seperti google meet, google classroom, dan E-learning. Sebagai suatu alat penghubung terjalinnya komunikasi antara guru dan peserta didik tanpa adanya kontak fisik. Berdasarkan hasil observasi dari kelas 1 SDN 16 PAGI tahun ajaran 2020/2021 tentang konsep guru melaksanakan pembelajaran daring pada masa pandemi COVID-19 dapat diambil beberapa kesimpulan tersebut dipaparkan sebagai berikut.

Sesuai dengan data yang diperoleh dari penelitian, pelaksanaan pembelajaran selama masa pandemi COVID-19 yang dilaksanakan pada kelas 1 SDN 16 PAGI tahun ajaran 2020/2021.Guru SDN 16 Pagi dalam melaksanakan pembelajaran di rumah atau Daring (dalam jaringan) pada masa Pandemi COVID-19 adalah memanfaatkan teknologi dan media sosial pada pembelajaran daring siswa di rumah, menjalin kerjasama yang baik dengan orang tua melalui grup WhatsApp selama pembelajaran daring di rumah. Beberapa aplikasi dan media yang digunakan guru adalah WhatsApp, Google Form, Google Meeting. Faktor Yang Mendukung Pelaksanaan Pembelajaran Daring Pada Masa Pandemi COVID-19 antara lain :

1. Tersedianya perangkat Handphone Android bagi sebagian besar wali murid

2. Mudahnya komunikasi antara guru dengan orang tua tentang kegiatan belajar siswa di rumah dengan memanfaatkan grup WhatsApp.

Sedangkan faktor yang menghambat antara lain keterbatasan penyimpanan pada telepon genggam masing-masing wali murid, tidak disiplin dalam hal waktu serta peran pendidikan cenderung lebih kepada orang tua dan guru hanya sebagai fasilitator.

\section{BIBLIOGRAPHY}

Dewi, A. F. (2020). Dampak COVID-19 Terhadap Implementasi Pembelajaran Daring Di Sekolah Dasar. Edukatif: Jurnal Ilmu Pendidikan

Dewi, Shinta Kurnia. 2011. Efektivitas E-Learning Sebagai Media Pembelajaran Mata Pelajaran TIK Kelas XI di SMA Negeri 1 Depok. Yogyakarta: Jurusan Pendidikan Teknik Informatika Universitas Negeri Yogyakarta

Dick, W, dkk.(2001). The systematic design of instruction-5th ed. London: Longman

Kementerian Kesehatan. (2020). Pedoman Pencegahan dan Pengendalian Coronavirus Disease (COVID-19)

Nur, A. M. (2011). Tugas Guru sebagai Pengembang Kurikulum. JURNAL ILMIAH DIDAKTIKA: Media Ilmiah Pendidikan dan Pengajaran, 12(1), 59-67.

Rahayu, Minto. 2009. Bahasa Indonesia di Perguruan Tinggi. Jakarta: PT Gramedia Widiasrana Indonesia.

Sari, P. (2015). Motivasi Belajar dengan Menggunakan E-Learning. Jurnal Ummul Quro, 6(2), 20-35.

Sugiyono (2015). Metode Penelitian Kuantitatif, Kualitatif, dan Kombinasi (Mix Methods). Bandung: Alfabeta. CV 
Devi Fitriya, Ina Magdalena dan Nur Fauziah Fadhillahwati/Cerdika: Jurnal Ilmiah Indonesia 1(3), 182-188

Suyono Hariyanto. (2016). Belajar dan Pembelajaran Teori dan Konsep Dasar. PT. Remaja Rosdakarya

Syaharuddin, S., \& Mutiani, M. (2020). STRATEGI PEMBELAJARAN IPS: Konsep dan Aplikasi.

Susanti, Lidia. (2020). Strategi Pembelajaran Berbasis Motivasi. Elex Media Komputindo.

Suardi, Moh. (2018). Belajar dan Pembelajaran. Yogyakarta: Deepublish.

Pohan, Albert Efendi. (2020). Konsep Pembelajaran Daring Berbasis Pendekatan Ilmiah. Purwodadi: CV Sarnu Untung.

Sarwa (2021). Pembelajaran Jarak Jauh: Konsep, Masalah dan Solusi. Indramayu: Penerbit Adab. 